\section{Epidemiologic trends of HIVIAIDS in Jamaica}

Idowu A. Olukoga 1

Key words: acquired immunodeficiency syndrome, HIV infections, sexually transmitted diseases, risk factors, sexual behavior, Jamaica.

\footnotetext{
1 University of KwaZulu-Natal, Division of Economics, Durban, South Africa. Send correspondence to: I. A. Olukoga, University of KwaZulu-Natal, Division of Economics, Durban 4041, South Africa; telephone: 2731260 2503; fax: 2731260 2811; e-mail: aolukoga@ yahoo.com
}

The Caribbean now ranks second to sub-Saharan Africa in terms of the number of cases of HIV/AIDS per capita. About $2.4 \%$ of the Caribbean's adult population is living with HIV / AIDS (1). HIV / AIDS has become the leading cause of death for persons 15 to 44 years old in several English-speaking and several non-English-speaking nations of the Caribbean, and it is also responsible for leaving an estimated 80000 Caribbean children orphaned (2). Jamaica is one of the Caribbean countries where the epidemic has spread from high-risk groups to the general population. The other Caribbean countries where this has happened are the Bahamas, Barbados, the Dominican Republic, Guyana, and Haiti (3).

There is a compulsory disease notification and surveillance system for the health sector in Jamaica. This system is coordinated by the Ministry of Health and generates various reports periodically for the relevant segments of the country. One of these reports is the Jamaica AIDS Report, whose 2001 edition served as the primary source of data for this study (4). There were 6038 cases of HIV/ AIDS reported to the Ministry of Health in Jamaica between 1982 and December 2001 (4). Of the total cumulative number of HIV/AIDS cases that had been reported in Jamaica by 1997, 55\% of them had died (5). An estimated 24000 to 32000 people are living with HIV / AIDS in Jamaica, representing $1.5 \%$ to $2.0 \%$ of the adult population. Many of those persons are uncertain of their HIV/AIDS status, thus contributing to a spread of the disease. Among the nations of the Caribbean, Jamaica has the third largest population of people living with HIV / AIDS, after the Dominican Republic and Haiti, two countries that together account for $85 \%$ of the total number of HIV/AIDS cases in the Caribbean $(2,3)$.

The magnitude of the HIV/AIDS problem in Jamaica is more striking when it is noted that $50 \%$ of the total cases recorded in the 20 years from 1982 to 2001 were recorded in only the 4 years of 1997 through 2000 (6). However, the reported cases give an incomplete picture since the underreporting of HIV/AIDS cases in the country is common, especially in the private health care sector (6-8).

Given that HIV / AIDS is emerging as a leading cause of death in Jamaica, there is a need for a critical look at the problem posed by the epidemic. This article reviews the epidemiology of HIV / AIDS in Jamaica by describing the distribution of, determinants of, and deterrents to the epidemic in the country. 


\section{DISTRIBUTION OF THE EPIDEMIC}

The first case of AIDS in Jamaica was diagnosed in November $1982(2,8,9)$. Since 1987 the annual HIV/AIDS case rate has doubled every two years, with $69 \%$ of infected individuals having died with AIDS (10). The reported incidence of HIV/ AIDS in Jamaica has steadily increased, with it being 0.05 per 100000 in 1982, 0.1 per 100000 in 1985, 20.2 per 100000 in 1995, and 36.26 per 100000 in $2001(4,11)$. Jamaica has had the largest increase in the rate of HIV/AIDS infection of any country in the Caribbean since 1997, according to the country's Ministry of Health (4). Jamaicans make up one out of every thirty new cases of HIV per year in the Caribbean (4). The following paragraphs discuss the distribution of the epidemic among a number of different groups in Jamaica, including adults, adolescents, children, men and women, populations with especially high risk, and residents of urban areas.

There was an estimated $0.7 \%$ of the adult population in Jamaica living with HIV/AIDS at the end of 1999 (12). This increased to $1.5 \%$ to $2.0 \%$ of the adult population in 2002 (3). HIV / AIDS and other sexually transmitted infections have become the number one cause of morbidity and mortality for both men and women in the age group of 30-34 years (12).

The age group that has made up the single largest share (17.8\%) of all the HIV/AIDS cases in Jamaica over the 1982-2001 period is that of persons 30-34 years old, closely followed by those 35-39 years old ( $16.4 \%$ of all the HIV / AIDS cases) and by those 25-29 years old (14.3\% of the cases) (Table 1). Those between 20 and 39 years old have accounted for a little less than $56 \%$ of all HIV/AIDS cases in the country: $34.2 \%$ of all the cases have been in the age group of $30-39$ years, and $21.4 \%$ of the cases have been in the age group of 20-29 years (Table 1).

Among adolescents the risk of HIV infection for females 10-19 years old was two to three times as high as the risk for boys of the same age group. This is as a result of young girls having sexual relations with older men who are HIV-infected (4).

It is estimated that every week in Jamaica two or three HIV-infected children are born. In 2001 there were 66 children under the age of 10 years newly reported with AIDS, a 20\% decrease from the previous year. This might be a result of a decline in the fertility of women with HIV/AIDS. HIV / AIDS was the second leading cause of death in Jamaican children aged 1-4 years old in 1999. In the three years prior to 2002, on average three children per month died of AIDS (4). A disturbing feature of the HIV / AIDS profile in Jamaica is the high proportion of the total number of reported HIV/AIDS cases, $6.6 \%$, that is made up of children who are $0-4$ years old (Table 1).
TABLE 1. HIV/AIDS cases in Jamaica, showing number and percent of total by sex and age, 1982-2001

\begin{tabular}{|c|c|c|c|c|c|c|}
\hline \multirow{2}{*}{$\begin{array}{l}\text { Age group } \\
\text { (years) }\end{array}$} & \multicolumn{2}{|c|}{ Male } & \multicolumn{2}{|c|}{ Female } & \multicolumn{2}{|c|}{ Total } \\
\hline & No. & $\%$ & No. & $\%$ & No. & $\%$ \\
\hline $0-4$ & 211 & 3.49 & 189 & 3.13 & 400 & 6.62 \\
\hline $5-9$ & 48 & 0.79 & 31 & 0.51 & 79 & 1.31 \\
\hline $10-14$ & 7 & 0.12 & 12 & 0.20 & 19 & 0.31 \\
\hline $15-19$ & 18 & 0.30 & 59 & 0.98 & 77 & 1.28 \\
\hline $20-24$ & 189 & 3.13 & 240 & 3.97 & 429 & 7.11 \\
\hline $25-29$ & 489 & 8.10 & 375 & 6.21 & 864 & 14.31 \\
\hline 30-34 & 655 & 10.85 & 420 & 6.96 & 1075 & 17.80 \\
\hline $35-39$ & 605 & 10.02 & 385 & 6.38 & 990 & 16.40 \\
\hline $40-44$ & 455 & 7.54 & 229 & 3.79 & 684 & 11.33 \\
\hline $45-49$ & 302 & 5.00 & 169 & 2.80 & 471 & 7.80 \\
\hline $50-54$ & 234 & 3.88 & 93 & 1.54 & 327 & 5.42 \\
\hline $55-59$ & 172 & 2.85 & 72 & 1.19 & 244 & 4.04 \\
\hline $60-64$ & 94 & 1.56 & 46 & 0.76 & 140 & 2.32 \\
\hline $65-69$ & 40 & 0.66 & 19 & 0.31 & 59 & 0.98 \\
\hline $70-74$ & 20 & 0.33 & 12 & 0.20 & 32 & 0.53 \\
\hline $75-79$ & 7 & 0.12 & 3 & 0.05 & 10 & 0.17 \\
\hline $80-84$ & 0 & 0.00 & 2 & 0.03 & 2 & 0.03 \\
\hline $85-89$ & 1 & 0.02 & 0 & 0.00 & 1 & 0.02 \\
\hline Unknown & 64 & 1.06 & 38 & 0.63 & 102 & 1.69 \\
\hline Total & 3636 & 60.22 & 2402 & 39.78 & 6038 & 100 \\
\hline
\end{tabular}

Source: Jamaica, Ministry of Health (4).

The cumulative male-to-female adult AIDS case ratio declined from 2.8:1 in 1988 to 1.9:1 in 1993 (7). By December 2001 about $40 \%$ of the cumulative number of those who had become infected with HIV in Jamaica were women (Table 1). Of the HIV/ AIDS cases reported in 2001, women accounted for $46 \%$ of the total, compared to $42 \%$ in the previous year. One group whose rate of infection is still much higher among men is that of persons who are over 50 years old: In men in that age group the risk of having HIV/AIDS was 2.5 times as high as the risk among women.

There are several population subgroups in Jamaica that are most at risk of becoming infected or of transmitting the HIV infection. These include commercial sex workers, with a $10 \%-20 \%$ prevalence; men who have sex with other men, with a $25 \%$ prevalence; prison inmates, with a $12 \%$ prevalence; and persons with past exposure to sexually transmitted infections, with a $6 \%$ prevalence. Mother-to-child-transmission of HIV accounts for $8 \%$ of new infections (3).

The HIV / AIDS epidemic has had the greatest impact in the urban areas of Jamaica (13). Some reports indicate that urban prevalence may be two to three times as high as rural prevalence $(14,15)$. All the parishes in Jamaica are affected by the epidemic. However, two parishes, St. James and Kingston/St. Andrew (KSA), have continued to have the highest HIV prevalence rates (4). This is 
TABLE 2. HIVIAIDS cases in Jamaica, by regional health authority and parish, showing total number of cases and cumulative rate, 1982-2001

\begin{tabular}{|c|c|c|}
\hline $\begin{array}{c}\text { Regional health } \\
\text { authority }(\mathrm{RHA}) / \text { Parish }\end{array}$ & $\begin{array}{l}\text { Cumulative total } \\
\text { no. of cases }\end{array}$ & $\begin{array}{l}\text { Cumulative rate per } \\
100000 \text { population }\end{array}$ \\
\hline \multicolumn{3}{|l|}{ North East RHA } \\
\hline Portland & 101 & 128.3 \\
\hline St. Ann & 321 & 207.0 \\
\hline St. Mary & 171 & 149.7 \\
\hline Subtotal/Overall & 593 & 167.2 \\
\hline \multicolumn{3}{|l|}{ South East RHA } \\
\hline Kingston/St. Andrew & 2576 & 367.0 \\
\hline St. Catherine & 758 & 203.5 \\
\hline St. Thomas & 98 & 109.7 \\
\hline Subtotal/Overall & 3432 & 280.8 \\
\hline \multicolumn{3}{|l|}{ Southern RHA } \\
\hline Clarendon & 199 & 89.2 \\
\hline Manchester & 167 & 95.5 \\
\hline St. Elizabeth & 125 & 85.1 \\
\hline Subtotal/Overall & 491 & 88.5 \\
\hline \multicolumn{3}{|l|}{ Western RHA } \\
\hline Hanover & 145 & 217.1 \\
\hline St. James & 925 & 552.6 \\
\hline Trelawny & 143 & 197.5 \\
\hline Westmoreland & 263 & 200.6 \\
\hline Subtotal/Overall & 1476 & 369 \\
\hline Overseas address & 8 & 0.0 \\
\hline Parish not known & 38 & 0.0 \\
\hline Total & 6038 & 232.2 \\
\hline
\end{tabular}

Source: Jamaica, Ministry of Health (4).

because the only two cities in Jamaica-Montego Bay (St. James) and Kingston (KSA) - are in these two parishes. In 1995 St. James had the highest cumulative case rate, of 155 per 100000 population (9). By 2001 this cumulative rate had more than tripled, reaching 552.6 per 100000 population (Table 2). The cumulative rate for St. James is about 2.5 times the national rate of 232.2. In a study of 4186 pregnant women attending the antenatal clinic at the University Hospital of the West Indies, in Kingston, women who were residing in urban Kingston and St. Andrew were found to be at greater risk for HIV infection than were the pregnant women from other areas of the country (16).

\section{DETERMINANTS OF THE EPIDEMIC}

A number of risk factors that have facilitated the spread of HIV/AIDS in Jamaica have been described in the scientific literature. Among these factors are early initiation of sexual activity, multiple sex partners, unprotected sexual intercourse, teenage pregnancy, drug abuse, presence of other sexually transmitted infections (STIs), tourism, poverty, and malnutrition.
The onset of sexual activity in Jamaica is early. In boys the mean age is 12.5 years (standard deviation (SD), 2.5 years) (17). By the age of $14,15 \%$ of girls and $47 \%$ of boys are sexually active (18). In $1996,41 \%$ of male adolescents in the 12-14 age group were reported to be regularly sexually active (3).

Having multiple sex partners is another of the factors fueling the HIV / AIDS epidemic in the country. Some men report having five or more sexual partners per year, and there is widespread acceptance of sex outside of marriage or other stable relationships (19). The pattern is similar for adolescents, with boys reporting a mean cumulative total number of 3.8 sexual partners $(\mathrm{SD}=2.4)$, and girls reporting a mean of $1.8(\mathrm{SD}=1.2)(17)$.

Unprotected sexual intercourse and teenage pregnancy also contribute to the epidemic. There is a common acceptance of STIs as a natural and easily curable outcome of sexual activity (19). Only $4 \%$ of 165 adolescents studied by Smikle et al. (17) used condoms consistently, and teenage pregnancy rates were as high as $13 \%$.

Drug abuse is another factor in Jamaica. As is true elsewhere in the Caribbean, the use of injecting or intravenous drugs facilitates HIV transmission through the sharing and reuse of contaminated injecting equipment, such as needles and syringes, as well as through sexual intercourse with regular or casual partners (20).

There is substantial evidence that STIs may increase the susceptibility of uninfected individuals to HIV and also increase the infectiousness of HIVpositive individuals. Control of STIs therefore has an important role in the primary prevention of HIV (21). Almost $50 \%$ of the syphilis and gonorrhea cases in Jamaica are among adolescents (18). Among Jamaican adolescents studied by Smikle et. al. (17), 33\% of them reported repeated episodes of STIs, $1.2 \%$ reported HIV coinfection with other STIs, and another $1.2 \%$ reported infection with syphilis.

Tourism is the leading foreign exchange earner for Jamaica. Gross foreign exchange earnings from the tourism sector in 1995 were an estimated US\$ 965 million (9). HIV transmission is well established locally and is spreading more rapidly in western Jamaica and along the north coast, which may reflect increased sexual activity associated with tourism (10). The increase in the number of tourists has attracted more people of various age groups into commercial sex work or "sex tourism" (22). Tourism has been identified as facilitating the spread of HIV in the Caribbean (20).

Poverty is known to increase people's vulnerability to HIV / AIDS because it may reduce their access to information, services, and commodities for HIV prevention, treatment, and care. In order to fi- 
nance their basic needs, poor persons may engage in specific high-risk behaviors such as having unprotected sex with individuals whose serostatus is unknown. Poverty is widespread in Jamaica, with $18.7 \%$ of the population living below the poverty line (3).

Malnutrition is another factor. Stephen et al. (23) did a review of 435 children admitted to the clinical research ward of the Tropical Metabolism Research Unit in Kingston from January 11990 through 31 December 1999. Among the 25 of those children with secondary severe childhood malnutrition, the HIV / AIDS group was the largest, comprising $60 \%$ of these admissions. Regression analyses also showed that the number of cases of secondary severe childhood malnutrition increased over that 10-year period.

\section{DETERRENTS TO THE EPIDEMIC}

Despite the increase in the number of HIV/ AIDS cases in Jamaica, there are some factors that have acted in concert to slow the spread of the epidemic. These factors include an efficient national health system, establishment of a national HIV/ AIDS control program, improved management of STIs, increased condom use and condom sales, reduced high-risk sexual behavior, and improved funding for HIV / AIDS control and prevention.

Jamaica has an efficient national health system. The health indicators in Jamaica are generally more favorable than those of other countries in Latin America and the Caribbean at similar income levels. The country was ranked 8th out of 191 countries in terms of health system efficiency, which the World Bank defined as the current population health level compared to the maximum possible for observed levels of health expenditure and education in a country (3).

Jamaica has had a comprehensive national HIV/STI control program since 1987 (19). That program has instituted HIV/STI control measures that appear to have slowed the HIV/AIDS epidemic (24). A national surveillance system for HIV infection and AIDS is based in the Epidemiology Unit of the Ministry of Health (10). In addition, the National AIDS Committee was established in 1988 to advise the Ministry of Health on policy issues and to mobilize different sectors of the society in the fight against HIV / AIDS (3).

Improved management of STIs has come about as a result of continuing medical education programs on the case management of STIs that have been organized periodically for all categories of medical doctors in Jamaica. The aim is to improve the quality and comprehensiveness of the management of STIs. This initiative has included programs for private medical practitioners, who manage $60 \%$ of all STI cases in the country (25).

The awareness of AIDS and HIV is high, and condom use has increased considerably (10). There has been a rise in the proportion of women ever having used condoms: the figure was $51.0 \%$ in 1988, $62.5 \%$ in $1992,73.0 \%$ in 1994 , and $73.0 \%$ in 1996 . Condom use during the last sexual encounter with a nonregular partner also increased, from $37 \%$ in 1992 to $73 \%$ in 1996. A high rate of condom use among men was reported, with $81 \%$ having ever used condoms and $77 \%$ using them during the last sexual encounter with a nonregular partner. Homosexual men, inner-city adults, and adolescents aged 12-14 years old have all reported increases in condom use. In addition, the number of condoms sold or distributed for free in Jamaica climbed from around 2 million in 1985 to 10 million in 1995 (24).

High-risk sexual behavior has decreased. The proportion of men aged 15-49 years reporting sex with a nonregular partner during the preceding year declined from 35\% in 1994 to 26\% in 1996 (24). Jamaican men who once readily had five or more sex partners per year are choosing their partners more carefully and staying in relationships longer. Women also report having fewer sex partners, and young male adolescents are waiting until they are older to begin having sex (19).

In 2002 the World Bank granted the Government of Jamaica a loan of US\$ 15 million for its HIV/AIDS control program. This makes up the bulk of the Jamaican funding to fight HIV/AIDS. The loan, coupled with US\$ 5 million in matching funds from the Government of Jamaica, is expected to strengthen the country's ability to monitor the disease, to do research, and to carry out surveillance $(2,3)$.

\section{HIV TRANSMISSION MECHANISMS IN JAMAICA}

HIV can be transmitted from one person to another in a number of ways. Three transmission mechanisms are the most important in Jamaica: heterosexual contact, mother-to-child, and homosexual/bisexual contact (Table 3).

Of the reported HIV infections in Jamaica over the $1982-2001$ period, $62 \%$ of them have resulted from heterosexual contact (12) (Table 3). Although the probability of transmitting HIV in a single act of intercourse can be quite low, a number of factors increase the risk of infection dramatically. The two most important ones are the presence in either partner of an STI, such as syphilis or gonorrhea, and having a large number of sexual partners. 
TABLE 3. Modes of transmission of HIV in Jamaica, showing the number of cases and their percent of the total, 1982-2001

\begin{tabular}{lrc}
\hline & \multicolumn{2}{c}{ Cases } \\
\cline { 2 - 3 } Transmission mode & No. & $\%$ \\
\hline Heterosexual & 3716 & 61.5 \\
Undetermined & 1482 & 24.5 \\
Mother-to-child & 479 & 7.9 \\
Homosexual/Bisexual & 345 & 5.7 \\
Intravenous drug use & 8 & 0 \\
Blood transfusion & 8 & 0 \\
$\quad$ Total & 6038 & $100 \%$ \\
\hline
\end{tabular}

Source: Jamaica, Ministry of Health (4).

A noticeable number of Jamaican adults suffer from STIs, and, as mentioned earlier, many adults have a number of sexual partners. Among women attending family planning clinics, $27 \%$ of them had at least one STI. There is a strong association between STIs and HIV infection in Jamaica, with 39\% of persons living with HIV/AIDS having a previous history of sexually transmitted infection (3). Programs designed to slow the spread of HIV need to focus on reducing transmission through sexual contact and on treating STIs (26).

Worldwide, about $25 \%$ to $40 \%$ of babies born to HIV-infected mothers will themselves be infected (26). In Jamaica, HIV seroprevalence among pregnant women in several parishes in the national sentinel surveillance system increased steadily in the 1990s, and it ranged between 1\% and 2\% in 1996 and 1997 (27). By 2002 about 8\% of new HIV infections were due to mother-to-child transmission (12).

Homosexual/bisexual transmission accounts for about $6 \%$ of new HIV infections in Jamaica (12). However, this is believed to be an underreported category due to strong social, cultural, and legal discrimination against same-sex relationships in the country $(8,20)$.

A disturbing feature of HIV/AIDS reporting in Jamaica is the $25 \%$ share of cases whose route of transmission is undetermined (Table 3). This shortcoming needs to be addressed in order to design intervention strategies that will reach the largest number of people who are at risk.

\section{CONCLUSION}

The HIV/AIDS epidemic in Jamaica has become well established and is now classified as generalized. It represents a growing concern in the country, and additional efforts and resources need to be mobilized to control and prevent it. This will involve the cooperation of the health sector and other public sectors in Jamaica, such as education and finance, as well as the private sector, voluntary groups, and nongovernmental organizations. An effective, strengthened response is urgently needed in order to adequately address this epidemic. The epidemic could spread both more quickly and more widely if this kind of response is lacking. Although awareness of AIDS and HIV is high and condom use has increased considerably, there are no grounds for complacency. Efforts to combat HIV/ AIDS should focus on such priority areas as behavior change communication to encourage safe sex practices and a delay in the initiation of sexual activity. Other priorities are the prevention and control of other STIs and the prevention of mother-tochild HIV transmission. Using existing technologies and interventions, other countries have been able to reduce the spread of HIV. These successes demonstrate the importance of sound prevention and treatment programs as well as political commitment, and they can serve as examples for Jamaica.

\section{SINOPSIS}

\section{Tendencias epidemiológicas de la infección por VIH y el sida en Jamaica}

De todos los países del Caribe, Jamaica es el que ha tenido el mayor incremento de las tasas de infección por VIH y sida en años recientes. El hecho de que 1,5 a $2 \%$ de su población adulta esté infectada lo convierte en el país con la tercera población más grande de personas infectadas por VIH o sida en el Caribe. Entre el momento en que se diagnosticó el primer caso en 1982 y fines de 2001, 6038 casos de infección por VIH o sida se notificaron a las autoridades sanitarias, la mitad de ellos entre 1997 y 2000. No obstante, hay una subnotificación de la infección por VIH y el sida en el país. De los casos que se notificaron en el período de 1982 a 2001, $60 \%$ eran de sexo masculino y $40 \%$ de sexo femenino, pero la proporción de casos en mujeres ha venido aumentando. Las principales vías de transmisión han sido la heterosexual (62\% de todos los casos notificados), la vertical de madre a hijo (8\%) y la homosexual o bisexual (6\%). Los adultos de 30 a 34 años de edad representaron $17,8 \%$ de todos los casos notificados de infección por VIH o sida, y las personas de 35 a 39 años comprendieron $16,4 \%$ del total. Los niños de 0 a 4 años constituyeron $6,6 \%$ de los casos de infección por VIHo sida notificados. En 1999, la infección por VIH y el sida juntas constituían la segunda causa de muerte en niños de 1 a 4 años. El riesgo de infección por VIH y sida en mujeres de 10 a 19 años fue dos a tres veces más alto que en varones de la misma edad. En hombres mayores de 50 años el riesgo de tener VIH o sida fue 2,5 veces más alto que en mujeres de la misma edad. Entre los factores que han facilitado la propagación de la epidemia de infección por VIH y sida en Jamaica figuran el inicio precoz de la actividad sexual, la presencia de 
varios compañeros sexuales, la falta de protección durante las relaciones sexuales y el turismo. La infección se ha visto contenida por un sistema de salud nacional bastante eficiente $y$ un programa muy completo de alcance nacional para el control de la infección por VIH y el sida. Las medidas de control deben centrarse en la comunicación orientada a lograr cambios de conducta, la prevención y el control de otras infecciones de transmisión sexual y la prevención de la transmisión de VIH de madre a hijo.

\section{REFERENCES}

1. Joint United Nations Programme on HIV/AIDS and World Health Organization. AIDS epidemic update. Geneva: UNAIDS/WHO; 2002

2. Hawkins BD. HIV/AIDS a predator in paradise. Black Issues Higher Educ. 2003;19(25):19-22.

3. World Bank. Jamaica - HIV/AIDS Prevention and Control Project (second phase of the multi-country HIV/AIDS prevention \& control APL for the Caribbean). Washington, D.C.: World Bank; 2002.

4. Jamaica, Ministry of Health. Jamaica AIDS report 2001. Kingston: $\mathrm{MOH} ; 2002$.

5. Bain BC. Improving community care for persons with the acquired immunodeficiency syndrome in Jamaica. West Indian Med J. 1998;47 Suppl 4:37-9.

6. World Bank. Jamaica - HIV/AIDS Prevention and Control Project. Washington, D.C.: World Bank; 2001.

7. Figueroa JP, Brathwaite AR. Is under-reporting of AIDS a problem in Jamaica? West Indian Med J. 1995;44(2):51-4.

8. Nicholls S, McLean R, Theodore K, Henry R, Camara B. Modelling the macroeconomic impact of HIV/AIDS in the English speaking Caribbean: the case of Trinidad and Tobago and Jamaica. S Afr J Econ. 2000;68(5):916-32.

9. Pan American Health Organization. Jamaica - country profile. In: Pan American Health Organization. Health in the Americas. 1998 edition. Washington, D.C., PAHO; 1998. Pp. 343-55.

10. Figueroa JP, Brathwaite A, Ward E, DuCasse M, Tscharf I, Nembhard O, et al. The HIV/AIDS epidemic in Jamaica. AIDS. 1995;9(7):761-8.

11. King SD, Wynter SH, Bain BC, Brown WA, Johnston JN, Delk AS. Comparison of testing saliva and serum for detection of antibody to human immunodeficiency virus in Jamaica, West Indies. J Clin Virol. 2000;19(3):157-61.

12. World Health Organization. Epidemiological fact sheets on HIV/AIDS and sexually transmitted infections - Jamaica. 2002 update. Geneva: WHO; 2002.

13. Gayle HD, Hill GL. Global impact of human immunodeficiency virus and AIDS. Clin Microbiol Rev. 2001:14(2): 327-35.

14. World Bank. Confronting AIDS: evidence from the developing world. Washington, D.C.: World Bank; 1998.

15. Loewenson R, Whiteside A. Social and economic issues of HIV/AIDS in Southern Africa. Harare: Southern Africa AIDS Information Dissemination Service; 1997.

16. Perry D, Reid M, Thame M, Fletcher $\mathrm{H}_{,}$ Mullings A, McCaw-Binns A, et al. HIV infection seroprevalence and risk factor study among pregnant women attending the Antenatal Clinic at the University Hospital of the West Indies, Kingston, Jamaica. West Indian Med J. 2002; 51(2):80-3.

17. Smikle MF, Dowe G, Hylton-Kong T, Williams E, Baum M. Risky behaviour in Jamaican adolescent patients attending a sexually transmitted disease clinic. West Indian Med J 2000;49(4):327-30.

18. Kauffman C, Hue L. Sustaining youth peer HIV/STD prevention education.
AIDS STD Health Promot Exch. 1997:(3): 3-7.

19. Henry K. Jamaicans begin to embrace safer sex. Aidscaptions. 1997;4(1):18-22.

20. Kovaleski SF. Poverty, drug abuse fuel Caribbean AIDS outbreak. AIDSlink. 1998:(49):6-7.

21. Isaksen J, Songstad NG, Spissoy A. Socioeconomic effects of HIV/AIDS in African countries. Bergen: Chr. Michelsen Institute; 2002.

22. Stillwaggon E. HIV transmission in Latin America: comparison with Africa and policy implications. S Afr J Econ. 2000:68(5):985-1011.

23. Stephen CA, Thame MM, Gray R, Barker D, Wilks R, Forrester TE, et al. Primary malnutrition. Can we always tell? West Indian Med J. 2002;51(3):14852.

24. Figueroa JP, Brathwaite AR, Wedderburn M, Ward E, Lewis-Bell K, Amon JJ, et al. Is HIV/STD control in Jamaica making a difference? AIDS. 1998;12 Suppl 2:S89-98.

25. Green M, Hoffman IF, Brathwaite A, Wedderburn M, Figueroa P, Behets F et al. Improving sexually transmitted disease management in the private sector: the Jamaica experience. AIDS. 1998; 12 Suppl 2:S67-72.

26. Policy Project. HIV/AIDS in Southern Africa - background, projections, impacts and interventions. Washington, D.C.: Futures Group International; 2001.

27. United States, Agency for International Development. HIV/AIDS profile: Jamaica. Washington, D.C.: USAID: 2000. 